\title{
Pulsing hydrology determines top-down control of basal resources in a tropical river-floodplain ecosystem
}

\author{
Kirk O. Winemiller,${ }^{1,5}$ Carmen G. Montaña, ${ }^{1,6}$ Daniel L. Roelke, ${ }^{1}{ }^{2}$ Ames B. Cotner,${ }^{2}$ José Vicente Montoya, ${ }^{1,7}$ \\ Luzmila Sanchez, ${ }^{3}$ Maria Mercedes Castillo, ${ }^{4,8}$ and Craig A. Layman ${ }^{1,6}$ \\ ${ }^{1}$ Department of Wildlife and Fisheries Sciences and Interdisciplinary Program in Ecology and Evolutionary Biology, \\ Texas A\&M University, College Station, Texas 77843-2258 USA \\ ${ }^{2}$ Department of Ecology, Evolution and Behavior, University of Minnesota, 1987 Upper Buford Circle, St. Paul, \\ Minnesota 55108 USA \\ ${ }^{3}$ Departamento de Limnología, Estación de Investigaciones Hidrobiológicas de Guayana, Fundación La Salle de Ciencias Naturales, \\ San Félix, Estado Bolivar 8050 Venezuela \\ ${ }^{4}$ Departamento de Estudios Ambientales, Universidad Simón Bolivar, Caracas 1080-A Venezuela
}

\begin{abstract}
Variable hydrology of rivers strongly affects biophysical factors that influence primary production and population densities, thereby affecting the relative influence of bottom-up and top-down processes in trophic networks. Many tropical floodplain rivers have sustained seasonal flood pulses driven by precipitation patterns of the Intertropical Convergence Zone. These changes in flow alter concentrations of dissolved nutrients, aquatic primary productivity, and per-unit-area densities of aquatic organisms. Therefore, one would predict that the strength of top-down effects of animals on basal resources should shift as the annual flood pulse progresses. We conducted a series of field experiments in a Neotropical lowland river to test for effects of hydrologic phase, habitat (in-channel vs. floodplain aquatic habitat), and benthic-feeding fish and meiofauna on particulate organic matter, chlorophyll, and benthic microalgae. Net ecosystem productivity of this oligotrophic river is higher during the low phase of the annual flood cycle, which is also when resident fishes are at highest densities and there is a seasonal influx of migratory benthic-feeding fish. We therefore hypothesized that top-down effects of benthic-feeding fish would fluctuate temporally, with strongest effects during low water levels. We found that fish controlled the abundance of particulate organic matter and algae on solid substrates, but not on sand, during falling- and low-water phases within both channel and floodplain habitats. Except for diatom assemblages, which responded to fish exclusion, the taxonomic structure of algal and meiofauna assemblages was not significantly influenced by fish-exclusion treatments, but varied in relation to habitat type and hydrologic phase. Meiofauna densities were highest during the low-water period; experimental exclusion of meiofauna during this period had a significant effect on accumulation of particulate organic matter in sand. By controlling abundance of important basal resources, fishes and meiofauna have a large potential to influence other components of this tropical ecosystem. Our findings emphasize the predictable, gradual, changes in consumer-resource interactions associated with the seasonal flood pulse in tropical river systems.
\end{abstract}

Key words: algae; benthos; consumer control; detritus; flood pulse; food web; migratory fish; Neotropics; sediment; Semaprochilodus; species interaction; trophic ecology.

\section{INTRODUCTION}

All natural ecosystems exhibit pulsing of abiotic factors (e.g., temperature, precipitation, solar irradiance) and biotic components (outbreaks, epidemics,

Manuscript received 26 September 2013; revised 15 January 2014; accepted 18 February 2014; final version received 12 March 2014. Corresponding Editor: A. D. Rosemond.

${ }^{5}$ E-mail: k-winemiller@tamu.edu

${ }^{6}$ Present address: Department of Applied Ecology, North Carolina State University, Raleigh, North Carolina 27695 USA.

${ }^{7}$ Present address: Centro de Ecología, Instituto Venezolano de Investigaciones Científicas (IVIC), Caracas 1020-A Venezuela.

${ }^{8}$ Present address: El Colegio de la Frontera Sur (ECOSUR)-Unidad Villahermosa, Villahermosa, Tabasco 86280 México. mass migrations) that can strongly influence ecological interactions and ecosystem processes (Yang et al. 2008, 2010). The relevance of a resource pulse for food-web dynamics is not only determined by the magnitude of the increase in resource abundance in relation to background levels, but also by the ratio of consumer and resource abundance. Consequently, a resource "pulse" can be produced by an influx of resources or by a sudden decline in the density of consumer populations. Streams, rivers, and estuaries are strongly subject to pulsing, with 
hydrology functioning as the fundamental driving variable. These pulses take on different spatial dimensions. For example, in their review of food webs of lotic ecosystems, Woodward and Hildrew (2002) emphasized changes in trophic interactions across the land-water interface, i.e., the lateral dimension, during the rise and fall of flood pulses. Also, subsidies of nutrients, detritus, and other resources received from riparian zones and watersheds vary along longitudinal fluvial gradients. High-flow pulses in some systems can directly influence assemblages of benthic macroinvertebrates and algae by dislodging and displacing organisms, suspending and redistributing sediments, and altering availability of key resources (Power et al. 2008). Changes in stream flow also influence resource subsidies (Marcarelli et al. 2011) and top-down effects of animals on basal resources (Power 1990, 1992, Basaguren et al. 1996, Pringle and Hamazaki 1997, Power et al. 2008). Successful prediction of ecological dynamics within fluvial systems, therefore, requires understanding of causal relationships between hydrology, physicochemical variables, and biotic components.

Most tropical rivers have seasonal flow patterns caused by precipitation dynamics of the Intertropical Convergence Zone. In many tropical regions, these flood pulses are highly predictable and cause gradual changes in concentrations of dissolved nutrients and densities of fishes and other aquatic organisms. For example, the Cinaruco River in the llanos region of South America has a sinusoidal flood cycle (Montoya et al. 2006; Appendix A), and fish-exclusion experiments have revealed that benthic-feeding fishes can regulate abundance of particulate organic matter on hard substrates (Winemiller et al. 2006). The magnitude of this topdown effect was much greater during the low-water phase when fish densities were highest. This pattern was observed despite the fact that, during the low-water phase, concentrations of dissolved inorganic nutrients and net ecosystem productivity of the water column and benthos are highest (Cotner et al. 2006, Montoya et al. 2006, Roelke et al. 2006).

We hypothesized that in the Cinaruco River, the relative magnitude of top-down control on aquatic basal resources should transition gradually in accordance with cyclical changes in water level and densities of fishes and other aquatic consumers. During the peak of the highwater period (e.g., July in the Cinaruco River), the connection of the river with its floodplain is maximized, with vast areas of savanna inundated $(>100$-fold increase in total area of aquatic habitat) and most resident fish species are dispersed within the flooded gallery forests and savannas. During the descending phase of the flood pulse, fish densities increase due to decreased habitat and an influx of migratory detritivorous fish of the family Prochilodontidae (Semaprochilodus kneri and S. laticeps, with the former being much more abundant).
The migratory fish are expected to play an especially important ecological role because of their high abundance during the dry season. These relatively large fish (S. kneri are up to $35 \mathrm{~cm}$ total length) feed in the productive floodplain of the Orinoco River and, as floodwaters recede, they seek major clearwater tributaries. Throughout the dry season, groups of Semaprochilodus are commonly observed feeding in shallow areas within the Cinaruco channel and floodplain lagoons. When the river again floods (May), these fish migrate en mass to the Orinoco River, where they spawn and then move onto flooded plains to feed. Thus, major consumers of benthic fine particulate organic matter are absent from the Cinaruco during about half the year.

Here, we build on previous research showing effects of benthic-feeding fish on aquatic basal resources in a tropical lowland river by conducting experiments to estimate the strength of top-down effects during different phases of the annual flood pulse (Fig. 1). Experiments were conducted simultaneously within littoral habitats of the river channel and floodplain lagoons, and were designed to examine fish effects on abundance and assemblage structure of benthic microalgae and meiofauna. Manipulations were designed to test the prediction that the migratory fish have greater influence on the benthic resources than the species-rich assemblage of small omnivorous and detritivorous fishes that also consume benthic resources, and that the magnitude of this effect varies according to the phase of the annual hydrological cycle (Fig. 1). The sandy sediments of the Cinaruco River support a diverse and abundant meiofauna dominated by rotifers, harpacticoid copepods, aquatic insects, nematodes, and oligochaetes, which also consume benthic algae and particulate organic matter. Meiofauna density and assemblage structure could be affected by fishes, either directly via predation or bioturbation, or indirectly via fish consumption of microalgae and other forms of fine particulate organic matter. To explore these possibilities, we also performed an experiment to test for a top-down effect of meiofauna on concentrations of particulate organic matter and chlorophyll during the low-water phase. Together, these experiments provide novel insight into the seasonally varying dynamics of top-down control on basal resource pools in this tropical river system.

\section{Methods \\ Study site}

The Cinaruco River flows $505 \mathrm{~km}$ with an estimated basin area of $11700 \mathrm{~km}^{2}$ shared between Colombia (11\%) and Venezuela (89\%). Our study area was located in a meandering $12-\mathrm{km}$ reach of the Cinaruco River located $40 \mathrm{~km}$ from its confluence with the Orinoco River in Venezuela (detailed map available in Montoya et al. 2006). Air temperature ranges from $24^{\circ}$ to $38^{\circ} \mathrm{C}$, with annual rainfall averaging $\sim 1300 \mathrm{~mm}$ (Sarmiento and Pinillos 2001). This region has a typical tropical wet/ 


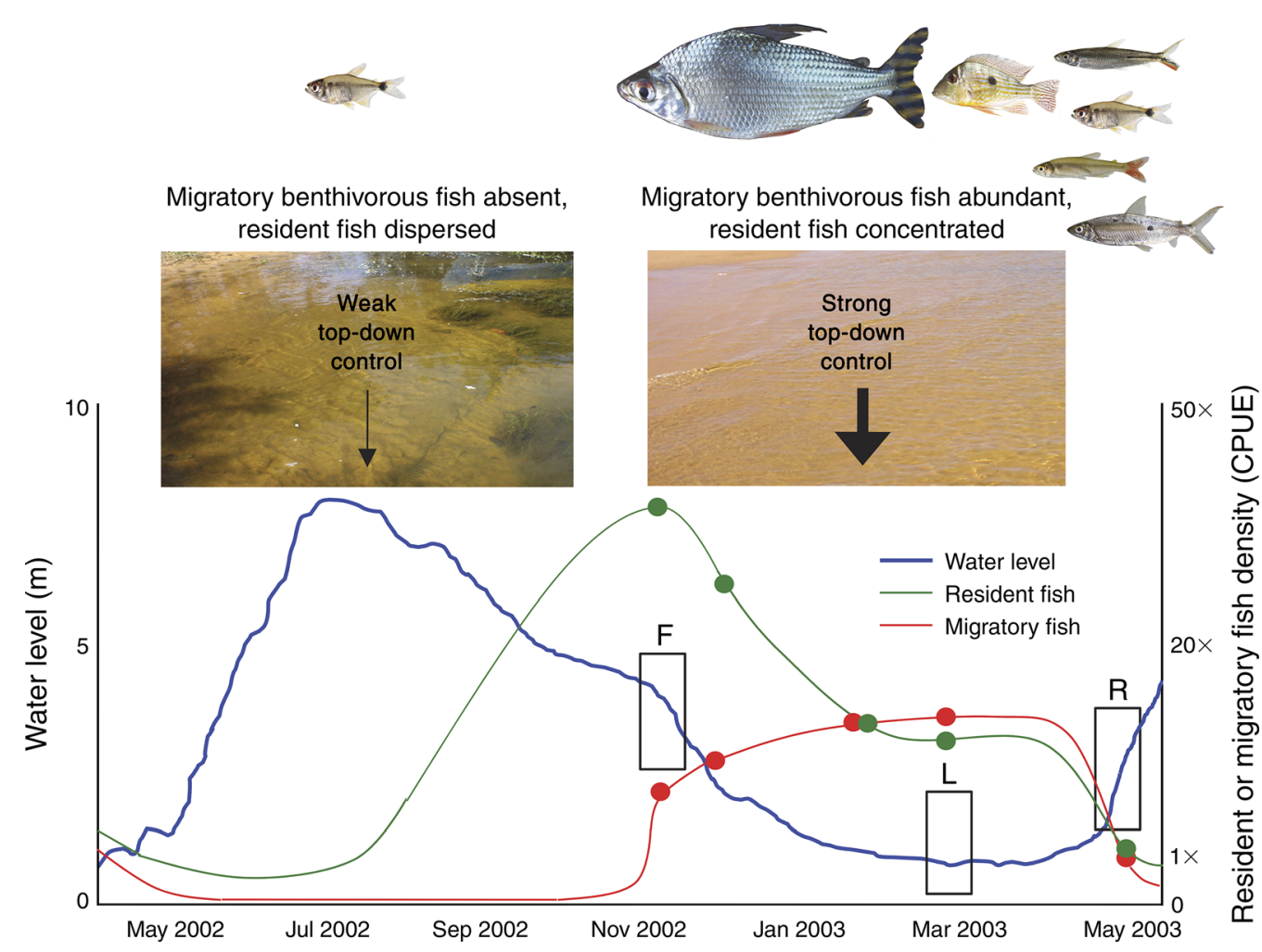

FIG. 1. Plot showing the Cinaruco River hydrograph (blue curve) and seasonal changes in densities (catch per unit effort; CPUE) of large migratory fish (red curve represents inferred pattern; red points are CPUE estimates from gillnet and cast net surveys with values standardized as multiples of the lowest recorded estimate from each method, $X$ ) and resident fishes (green curve represents inferred pattern; green points are CPUE estimates from gillnet and seine net surveys standardized as for the large migratory fishes). The relative strength of the top-down effect of benthic-feeding fish on accumulations of fine particulate organic matter and algae on sediments of the Cinaruco River is predicted to undergo gradual transition in accordance with the annual hydrological cycle that influences per-unit-area fish densities. During the annual low-water phase, most of the top-down influence is from feeding by migratory prochilodontids, but these fish are absent from the river during the annual flood pulse. Black boxes indicate the three periods when field experiments were conducted (falling water $[\mathrm{F}]$, low water $[\mathrm{L}]$, and rising water $[\mathrm{R}]$ ).

dry climate dominated by northeast trade winds and north-south migration of the Intertropical Convergence Zone. The wet season is from May to November (peaking in June-July). A hydrograph of the Cinaruco River in this reach was constructed from daily stageheight readings (Appendix A), and fieldwork for this study was conducted during three phases (falling, low, rising) of the sinusoidal hydrograph in 2002-2003 (Fig. 1).

The Cinaruco is one of only a few left-bank tributaries of the Orinoco without headwaters that extend into the Andes Mountains. Such rivers have low nutrient and suspended sediment loads because of the dystrophic character of llanos soils (Medina and Silva 1990, Cotner et al. 2006). Vegetation of this seasonally flooded terrain is mostly composed of grasses, sedges, and isolated small trees, with gallery forests along watercourses. Plant material of terrestrial origin is the most important substrate supporting microbial respiration during the annual falling-water period, but autochthonous production is also an important carbon source within littoral habitats (Roelke et al. 2006). During the falling- and low-water phases of the annual hydrograph, littoral habitats are net autotrophic, with water-column primary production $\left(150-500 \mathrm{mg} \mathrm{C} \cdot \mathrm{m}^{-2} \cdot \mathrm{d}^{-1}\right)$ more than 20 times greater than community water-column respiration. Benthic primary production in these habitats $(350-500$ $\left.\mathrm{mg} \mathrm{C} \cdot \mathrm{m}^{-2} \cdot \mathrm{d}^{-1}\right)$ is approximately equal to community benthic respiration (Cotner et al. 2006, Roelke et al. 2006). Thus, in terms of net ecosystem productivity of littoral habitats, the water column is more autotrophic than the benthos, and it is assumed that much of the microalgae and other fine particulate organic matter that accumulate on the surface of substrates originate in the water column (Cotner et al. 2006, Winemiller et al. 2006).

Based on seine, gillnet, and cast-net surveys, the catch-per-unit effort (CPUE) of both resident and migratory fish is at its minimum during the peak of the annual flood pulse when the lower Cinaruco River floods. CPUE of small resident fish is nearly 40 times higher during the falling-water period (Fig. 1), and their 
density and size gradually decline throughout the dry season as predation reduces these populations (Winemiller et al. 2006, Montaña et al. 2011). Migratory fish are absent from the Cinaruco River during the flood pulse, and CPUE of migratory fish increases rapidly during November-December and peaks during MarchApril when water level is lowest (Fig. 1).

\section{Experimental test of fish effects in relation to habitat and hydrologic period}

Experiments were conducted from 30 November until 8 December 2002 (falling water), 15 March to 2 April 2003 (low water), and 18 May to 28 May 2003 (rising water) to test effects of habitat type, hydrologic period, and fish on accumulation of sediment ash-free dry mass (SAFDM), chlorophyll $a$ concentration (CHLA), and the density and taxonomic assemblage structure of benthic algae and meiofauna. The experiment was a factorial design (three treatments $\times$ three periods $\times$ two habitat types) with treatments being large fish exclusion, total fish exclusion, and control. During the fallingwater period, 16 blocks, with each containing all three treatments, were constructed in both river channel and lagoon sites; during the low- and rising-water periods, 12 blocks were constructed in both channel and lagoon sites. The number of blocks was lower for some statistical tests because sediment samples or exclosures had been compromised (e.g., rising water completely submerged cages in four of 24 blocks during the risingwater period). During the low-water period, a fourth treatment, Semaprochilodus kneri enclosure (SK), was included. The SK treatment could not be created during rising- and falling-water periods, because these fish were actively migrating and, when confined in cages, failed to feed while continually attempting to escape. Therefore, this treatment was excluded from factorial ANOVA, but was included as a fourth treatment in a $4 \times 2$ ANOVA performed separately using results from the low-water period.

Experimental blocks were placed in locations within the river channel with low flow velocities $(0-0.20 \mathrm{~m} / \mathrm{s})$ and in areas within lagoons with similar depth and substrate (sand) that had no flow. The total-fishexclusion (TFE) treatment was a four-sided cage (1.8 $\times 1.8 \mathrm{~m}$ ) with an $0.7-\mathrm{cm}$ mesh wire screen that excluded all fishes. The large-fish-exclusion (LFE) treatment was a four-sided cage of the same dimensions with $2.5-\mathrm{cm}$ mesh poultry wire that excluded only large fishes, including large benthic grazers, but allowed small benthic-feeding fishes and invertebrates to pass. The $S$. kneri enclosure (SK) treatment was a four-sided cage of the same dimensions with $2.5-\mathrm{cm}$ mesh that confined two adult $S$. kneri within the experimental area $(0.6$ individuals $/ \mathrm{m}^{2}$ ) and allowed small fishes to pass. The per-unit-area density of $S$. kneri in the river is difficult to estimate with precision, but our cage density was $<0.5$ standard deviation above the mean density estimated for $S$. kneri in the littoral zone of lagoons during March
(Winemiller et al. 2006), and is the same as the mean density reported by McIntyre et al. (2008) for another migratory prochilodontid, Prochilodus mariae, during the dry season within Las Marias River, Venezuela. Feeding by captive $S$. kneri was verified by the presence of grazing scars on ceramic tiles and examination of stomach contents of euthanized specimens at the completion of trials. The control (CTRL) treatment was an area measuring $1.8 \times 1.8 \mathrm{~m}$ adjacent to one side of a cage. Debris accumulation on cages was minimal and was removed every other day. Experiments ran for six days, which previous research indicated was sufficient for accumulation of significant amounts of fine particulate organic material on tiles in fish-exclusion cages in this system (Winemiller et al. 2006).

\section{Measurement of fine particulate organic matter and chlorophyll}

At the beginning of each experiment, three ceramic tiles $(25 \times 6.4 \mathrm{~cm})$ were placed inside each experimental plot to provide a portable hard substrate upon which particulate organic matter and algae could accumulate. After six days, tiles and sand samples were removed from each plot for analysis. Tiles were gently lifted from the water, and all material on the tile surface was brushed and rinsed with well water into a plastic pan. Material obtained from tile samples was immediately frozen and stored in a freezer at the field site before being transported to a laboratory for processing. Sand samples were taken within each plot $(n=3)$ using a plastic Petri dish (5 $\mathrm{cm}$ diameter, $1.3 \mathrm{~cm}$ height). The Petri dish was pushed into the substrate, and a spatula was placed under the Petri dish to trap the contents during retrieval. Petri dishes were covered, sealed, kept frozen, and stored in the dark until analyses were performed. Half of each sample from each plot was dried and then combusted $\left(500^{\circ} \mathrm{C}\right.$ for $\left.3 \mathrm{~h}\right)$ and weighed to obtain SAFDM mass per unit area $\left(\mathrm{g} / \mathrm{m}^{2}\right.$ calculated from the surface areas of tiles and Petri dishes). Chlorophyll $a$ and phaeophytin $a$ concentrations (mg/ $\mathrm{m}^{2}$ ) were determined using the overnight $90 \%$ acetone extraction protocol using spectrofluorometric and spectrophotometric methods (APHA 1998). Chlorophyll $a$ values were corrected for phaeophytin.

\section{Algal abundance and assemblage composition}

Algal cells were obtained from the material scraped from tiles by adding $100-150 \mathrm{~mL}$ of distilled water to the sample, stirring the mixture, and then decanting the water and suspended particles. Subsamples of measured volumes were preserved with $4 \%$ formalin and stored in glass vials in a dark room until determination of algal taxonomic composition, abundance, and biovolume. Algal counts were done according to the Utermöhl (1958) method with the aid of sedimentation chambers, an inverted microscope, and image analysis software (ImageJ, Image, Bethesda, Maryland, USA; Abramoff et al. 2004). Algae biovolume was estimated according 
to Sun and Liu (2003) and Hillebrand et al. (1999), whereby the density of each taxon was multiplied by the average of its cell biovolume. Biovolume calculations were done from digital photographs using the analysis software Image (Image, Bethesda, Maryland, USA). Algal biomass was estimated by converting cell volumes to biomass assuming a specific density of $1 \mathrm{~g} / \mathrm{cm}^{3}$ (Nauwerck 1963). Algal taxa in each sample were identified to the lowest level feasible (usually to genus) and enumerated. After acid cleaning diatoms, permanent slides were made using Naphrax (PhycoTech, St. Joseph, Michigan, USA; Hasle and Fryxell 1970). The principal taxonomic reference texts were Bourrelly (1966, 1970), Krammer and Lange-Bertalot (1988, 1991), and Metzelin and Lange-Bertalot (1998). Time required for this laboratory work constrained our analysis of algal assemblages to five randomly selected experimental blocks from each habitat type.

\section{Meiofauna abundance and assemblage composition}

Samples of meiofauna (see Plate 1) within sand were taken at three randomly chosen locations within each plot using a core sampler $(5.5 \mathrm{~cm}$ diameter) to a depth of 10 $\mathrm{cm}$. Samples were placed in a container, and a $6 \%$ magnesium chloride $\left(\mathrm{MgCl}_{2}\right)$ solution was added to anesthetize organisms before fixation. Fixation and short-term preservation were accomplished using $10 \%$ formalin. Each replicate was sieved using a $63-\mu \mathrm{m}$ and a $500-\mu \mathrm{m}$ sieve. Organisms retained on the $500-\mu \mathrm{m}$ sieve, usually chironomid larvae, Campsurus nymphs, and oligochaete worms, were preserved and stored separate from smaller organisms. Material retained on the $63-\mu \mathrm{m}$ sieve, including organic debris, mineral particles, and meiofauna, was separated using a density gradient technique (Palmer et al. 2007) using a silica suspension (Ludox, Sigma-Aldrich, St. Louis, Missouri, USA). The supernatant, containing suspended meiofauna in Ludox, was poured on a $63-\mu \mathrm{m}$ sieve and retained organisms rinsed with reverse osmosis water. This extraction procedure was repeated twice per sample. The extracted organisms were placed in plastic bottles containing $10 \%$ buffered rose bengal and formalin solution. Meiofauna were examined under an inverted microscope and counted, taking subsamples until 200-300 organisms were counted per sample. Organisms were identified to the lowest feasible taxonomic level using keys from published and internet sources. Extraction procedure efficiency was assessed by microscopic examination of subsamples of residual pellets for comparison with extracted samples. Meiofauna extraction efficiency ranged between $74 \%$ and $100 \%$. Analysis of meiofauna assemblages was performed on five randomly selected experimental blocks from each habitat type during each period.

\section{Experimental test of meiofauna effects}

We also performed an experiment during April 2010 (low water) to test for potential influence of meiofauna as consumers of particulate organic matter on sedi- ments. Meiofauna were removed from sediments using two methods. In each case, a plastic square pan, measuring $22 \mathrm{~cm}$ by side $\times 10 \mathrm{~cm}$ tall, was used to scoop up a layer of sand approximately $5 \mathrm{~cm}$ deep. In one treatment, the sand was transferred to a bucket with stream water and the sand was stirred and water containing small particles was decanted. This process was repeated 10 times, after which the sand was returned to the plastic pan for placement of the pan with sand back into the site where the sand had been obtained. In the other treatment, the same amount of sand was collected in a plastic pan of the same size, and then the sand was transferred to a metal pot with stream water and boiled for $15 \mathrm{~min}$. The sterilized sand was rinsed once with river water, and the sand was placed into the plastic pan for placement back into the same site. This treatment should have eliminated not just meiofauna, but also microalgae attached to sand particles that would have seeded in situ population growth. The control treatment for this experiment consisted of the same amount of sand that was gently collected in a plastic pan of the same size, with immediate placement on the same location within the plot. Plots containing pans with all three of these treatments were enclosed according to the TFE protocol described in Methods, experimental test of fish effects in relation to habitat and hydrologic period to eliminate grazing by fishes of any size. If meiofaunal grazers reduce algae and other organic matter from sediments, expected accumulations of material among treatments would be sterilized and decanted being approximately equal and greater than control (assuming here that the two meiofauna removal methods have approximately equivalent effectiveness). Eight experimental blocks (with cages containing all three treatments) were established in both river channel and lagoon sites, and experiments ran for six days. Sand core samples for analysis of SAFDM and CHLA were obtained with a Petri dish in the same way. Data were standardized as $\left(x_{2}-x_{1}\right) / x_{1}$, where $x_{1}$ is the amount of material in the plot on day 0 and $x_{2}$ is the amount measured on day 6 .

\section{Statistical analyses}

The first set of experiments tested the hypothesis that large grazing fish reduced particulate organic matter and chlorophyll $a$ that accumulated on substrates in the littoral zone (SAFDM and CHLA accumulation in LFE $>$ CTRL), and that the guild of small grazing fishes consumed additional material and further reduced standing mass of particulate organic matter and algae (SAFDM and CHLA accumulation in TFE > LFE). The null hypothesis here was that neither large nor small fish influenced the accumulation of SAFDM and CHLA on tiles and in sand, or the abundance of benthic algae on tiles and meiofauna in sand $(\mathrm{TFE}=\mathrm{LFE}=\mathrm{CTRL})$. In addition, during the low-water period, we also tested whether or not the seasonal high abundance of migratory S. kneri, stocked at per-unit-area densities 
TABLE 1. Results of ANOVA for experiments testing effects of habitat type (river channel, lagoon), hydrologic periods (falling, low, rising), and fish-exclusion treatments (CTRL,

TFE, LFE) on accumulation of particulate organic material (SAFDM) and chlorophyll $a$ (CHLA) on different substrates (tiles, sand).

\begin{tabular}{|c|c|c|c|}
\hline Substrate and variables & $F$ & $\mathrm{df}$ & $P$ \\
\hline \multicolumn{4}{|l|}{ Tile } \\
\hline \multicolumn{4}{|l|}{ SAFDM } \\
\hline Habitats & 1.32 & 1,215 & 0.252 \\
\hline Periods & 4.09 & 2,215 & 0.018 \\
\hline Fish & 38.13 & 2,215 & $<\mathbf{0 . 0 0 0 1}$ \\
\hline Interaction & 2.70 & 4,215 & 0.031 \\
\hline \multicolumn{4}{|l|}{ CHLA } \\
\hline Habitats & 13.86 & 1,214 & 0.003 \\
\hline Periods & 31.59 & 2,214 & $<\mathbf{0 . 0 0 0 1}$ \\
\hline Fish & 37.18 & 2,214 & $<\mathbf{0 . 0 0 0 1}$ \\
\hline Interaction & 3.02 & 4,214 & 0.019 \\
\hline \multicolumn{4}{|l|}{ Sand } \\
\hline \multicolumn{4}{|l|}{ SAFDM } \\
\hline Habitats & 231.54 & 1,215 & $<\mathbf{0 . 0 0 0 1}$ \\
\hline Periods & 68.56 & 2,215 & $<0.0001$ \\
\hline Fish & 0.31 & 2,215 & 0.734 \\
\hline Interaction & 0.46 & 4,215 & 0.763 \\
\hline \multicolumn{4}{|l|}{ CHLA } \\
\hline Habitats & 26.85 & 1,214 & $<\mathbf{0 . 0 0 0 1}$ \\
\hline Periods & 241.70 & 2,214 & $<\mathbf{0 . 0 0 0 1}$ \\
\hline Fish & 0.93 & 2,214 & 0.395 \\
\hline Interaction & 0.81 & 2,214 & 0.517 \\
\hline
\end{tabular}

Notes: Bold type indicates significant effects $(P<0.05)$, except for tests that involved multiple related comparisons, in which case the critical $P$ value was adjusted according to the Bonferroni method ( $P=0.05 /$ number of related tests). For the fish-exclusion experiment, tile and sand substrates were considered related tests for the same response variable; however, results for the four response variables (SAFDM, CHLA, algae biovolume, and meiofauna density) were independent and therefore not considered related tests.

typical for this period, were capable of reducing accumulation of organic material on sediments (SK $<$ TFE), possibly to levels commensurate with the total top-down control naturally exerted by grazers overall $(\mathrm{SK}=\mathrm{CTRL})$. Here, the null hypothesis was that $S$. kneri did not affect accumulation of particulate organic matter and algae on sediments $(\mathrm{SK}=\mathrm{TFE})$.

Factorial analysis of variance (ANOVA) was used to test effects of habitat types, hydrologic periods, fishexclusion treatments, and their interactions on concentrations of SAFDM, CHLA on tiles and sand, microalgae density on tiles, and meiofauna density in sand. Prior to statistical analyses, values were $\log _{10}$-transformed to achieve distributions suitable for parametric tests. In the case of algae and meiofauna abundance data, we used $\log _{10}(x+1)$ to account for zero values. When ANOVA resulted in significance for independent variable without a significant interaction, statistical significance of pairwise mean differences among independent variables was tested using the Tukey-Kramer HSD test. For the meiofauna removal experiment, a $2 \times$ 3 factorial ANOVA was used to test effects of habitat types and experimental manipulations on accumulations of SAFDM and CHLA. Results yielding $P<0.05$ were considered statistically significant, except for tests that involved multiple related comparisons, in which case the critical $P$ value was adjusted according to the Bonferroni method ( $P=0.05 /$ number of related tests). For the fishexclusion experiment, tile and sand substrates were considered related tests for the same response variable; however, results for the four response variables (SAFDM, CHLA, algae biovolume, meiofauna density) were independent and therefore not considered related tests. For each response variable in the fish-exclusion experiments, there were 24 possible pairwise mean comparisons of treatments within a given habitat type during each of three periods. For the meiofaunaexclusion experiment, there were six possible mean comparisons between treatments within each of two habitat types. These statistical tests were performed using JMP Pro.10.0 (SAS Institute, Cary, North Carolina, USA).

Nonmetric multidimensional scaling (NMDS; Clarke 1993) was performed using Primer, version 5 (Clarke and Warwick 2001) to characterize differences in meiofauna and algae assemblages in relation to fish exclusions, hydrologic periods, and habitats. The data matrix consisted of mean density (meiofauna [organisms $/ \mathrm{m}^{2}$ ]; algae [biovolume $/ \mathrm{cm}^{2}$ ]) of each genus for each treatment within each habitat and period. Prior to running NMDS, the matrix of $\log (x+1)$-transformed mean densities of meiofauna (or algae) within the various plots was used to calculate a Bray-Curtis similarity matrix. To test whether species assemblages of algae and meiofauna were different according to habitat types, hydrologic periods, or fish-exclusion manipulations, we performed a one-way analysis of similarity (ANOSIM; Clarke and Warwick 2001).

\section{Results}

\section{Effects of hydrologic period, habitat, and fish on chlorophyll and particulate organic matter}

The fish-exclusion treatment and hydrologic period had a significant influence on SAFDM and CHLA on tiles (Table 1). CHLA accumulation was also significantly influenced by habitat type. The strength of topdown effects of fish on particulate organic matter (SAFDM) and algae (CHLA) that accumulated on the surface of tiles was largest during the falling-water and low-water periods, and smaller during the rising-water period (Fig. 2). During the falling-water period, the magnitude of fish effects on SAFDM on tiles was stronger in the channel than in lagoons (Fig. 2); however, the LFE treatment had significantly more SAFDM and CHLA than the CTRL in both habitat types during both the falling- and low-water periods (Table 1). During the low-water phase, SK and CTRL treatments were not significantly different, and the LFE treatment was significantly greater than the SK treatment. Accumulation of SAFDM and CHLA in the TFE treatment was not significantly greater than LFE during 

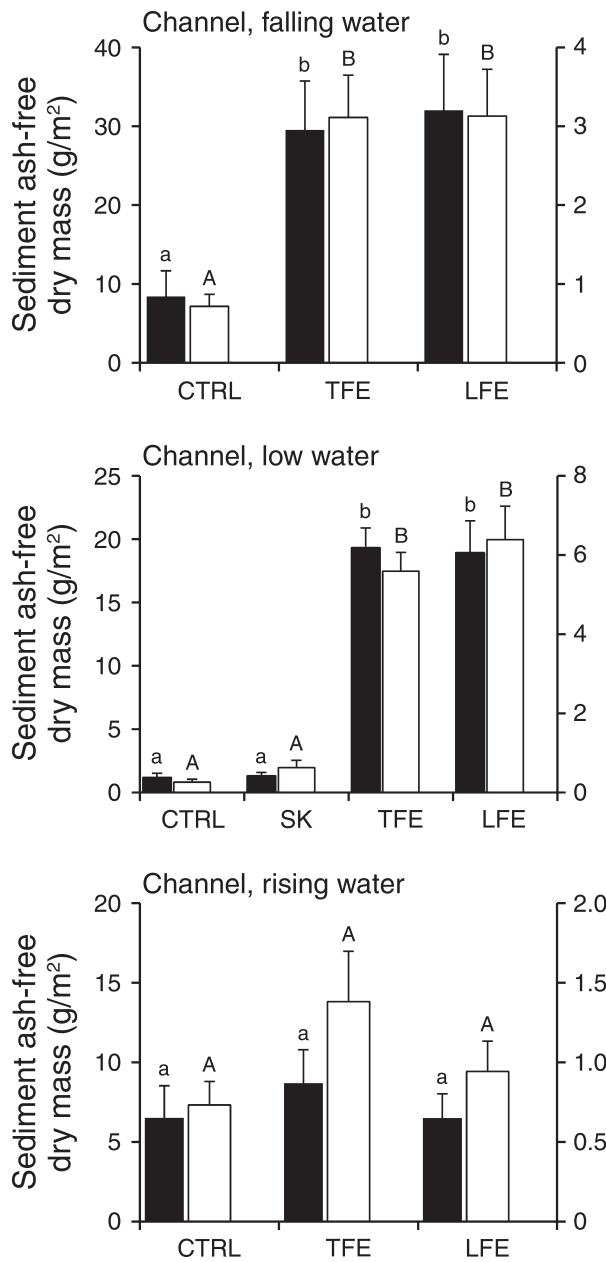
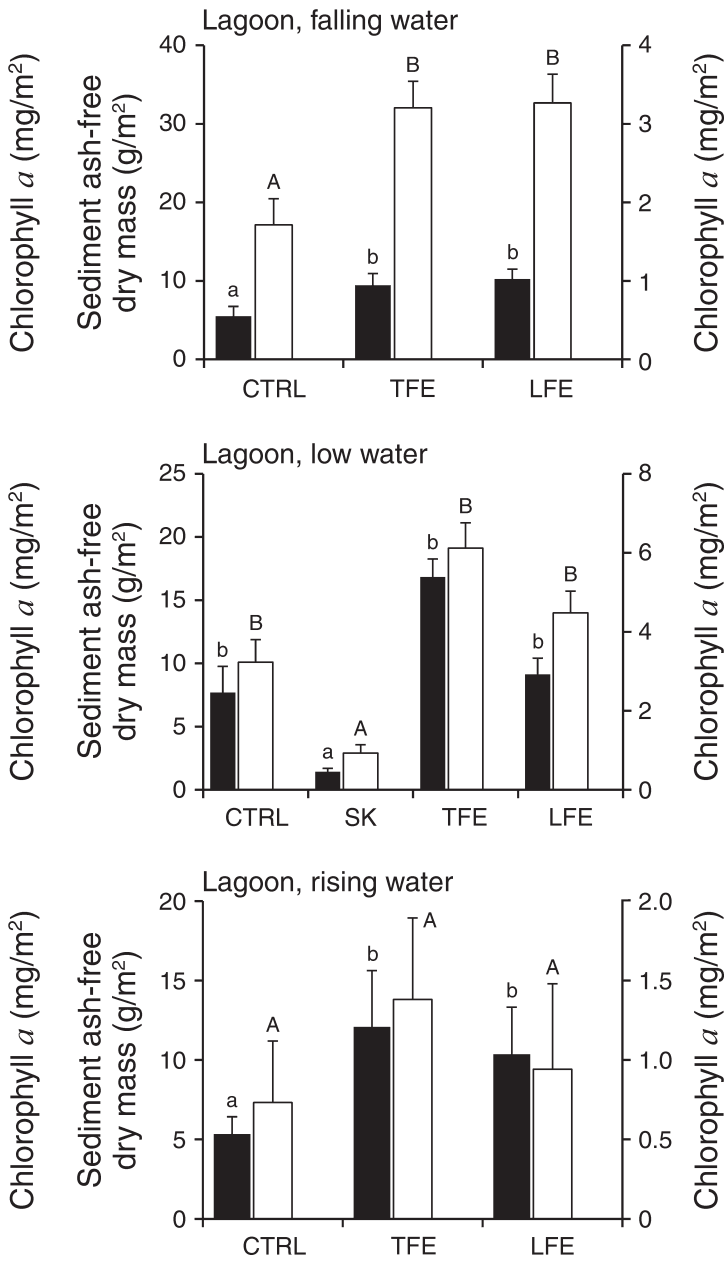

FIG. 2. Sediment ash-free dry mass (mean + SE; black bars) and chlorophyll $a$ (mean + SE; white bars) measured on the surface of tiles from 6-d experiments conducted in the river channel and lagoons during three hydrological seasons. Treatments included control (CTRL), total fish exclusion (TFE), large fish exclusion (LFE), and Semaprochilodus kneri enclosure (SK). Different lowercase letters designate significantly different $(P<0.05)$ mean differences between treatments for sediment ash-free dry mass within a given season and habitat; upper-case letters designate the same for chlorophyll $a$.

any hydrologic phase, which indicates that small grazing fishes had little top-down influence on benthic particulate organic matter and algae. During the rising-water period, when Semaprochilodus migrate downstream and exit the river, there were no statistically significant treatment effects on material collected from tiles, and amounts were not significantly different between the lagoons and the river channel. During the falling- and low-water periods, channel sites had greater accumulation of SAFDM and CHLA than lagoons (Fig. 2, Table 1). Experimental results based on material collected from sand were different than those from tiles. Concentrations of SAFDM and CHLA on sand showed no significant effects of fish exclusion during any period (Fig. 3, Table 1). Accumulations of SAFDM and CHLA on sand during all three periods were significantly greater in lagoons than in the channel.

\section{Effects of hydrologic period, habitat, and fish on algal assemblages}

Diatoms (Diatomophyceae) and, to a lesser extent green algae (Zygnematophyceae), dominated algal assemblages on tiles during every period. Assemblage structure of algae on tiles revealed significant seasonal variation in both channel and lagoon sites (Appendices $\mathrm{B}, \mathrm{C}$, and D). Abundance of a few dominant genera within these groups varied according to experimental treatment in addition to season and habitat type (Appendices D and E). Experimental treatments only resulted in two statistically significant differences in algal assemblage structure overall: in the river channel for TFE vs. SK during the low-water period ( $R=0.420, P=$ 0.002 ), and in lagoons for LFE vs. SK during the lowwater period $(R=0.216, P=0.003)$.

The total biovolume of diatoms and green microalgae on tiles was not predicted by habitat type or hydrologic 

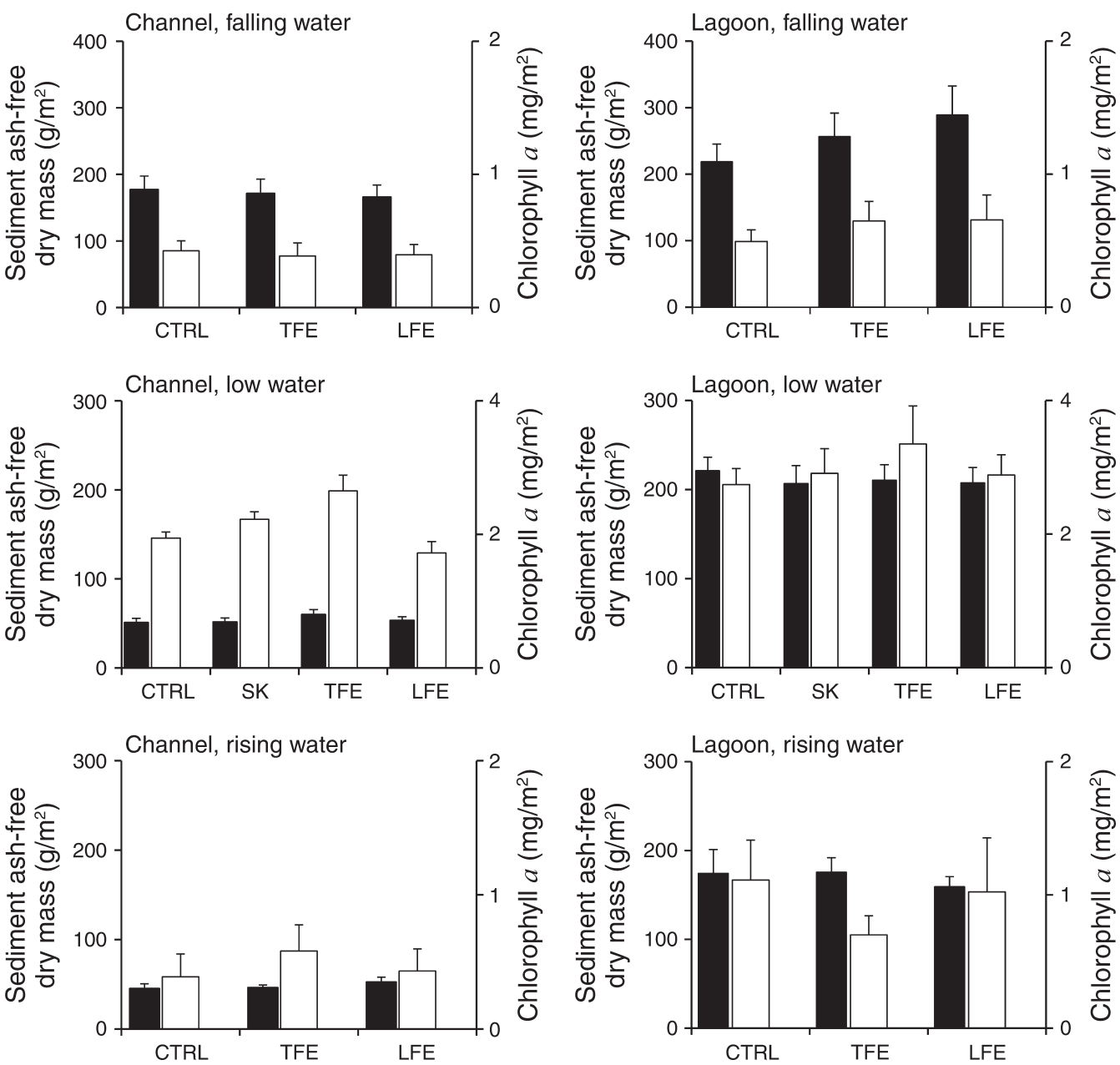

FIG. 3. Sediment ash-free dry mass (mean + SE; black bars) and chlorophyll $a$ (mean + SE; white bars) from the surface of sand from 6-d experiments conducted in the river channel and lagoons during three hydrological seasons. Treatments and abbreviations are as in Fig. 2. No mean differences were obtained between treatments for either of the response variables during any of the seasons and habitats.

period, but was significantly different among experimental treatments (Table 2). Diatoms varied much more among treatments than did green microalgae (Fig. 4). Mean algal biovolume was significantly greater in fishexclusion plots (compared to controls) in lagoons during the falling-water period and in the river channel during the low-water period. Semaprochilodus enclosures had lower mean algal biovolume than controls and fishexclusion plots in lagoons during the low-water period (Fig. 4).

\section{Effects of hydrologic period, habitat, and fish on meiofauna assemblages}

Assemblage structure of meiofauna varied significantly in relation to both habitat and hydrologic period but not fish-exclusion treatments (Appendices B, C, F, and G), except that meiofauna assemblage structure was significantly different between TFE and LFE in lagoons
TABLE 2. Results of ANOVA for experiments testing effects of habitat type, hydrologic periods, and fish-exclusion treatments on the combined biovolume of two dominant taxa of algae (Diatomophyceae, Zygnematophyceae) on tiles, and the combined abundance of three dominant meiofauna taxa (Rotifers, Crustacea, Insecta) within sand.

\begin{tabular}{lrcc}
\hline \hline $\begin{array}{c}\text { Dependent and } \\
\text { independent variable }\end{array}$ & $F$ & df & $P$ \\
\hline Algae & & & \\
Habitats & 0.55 & 1,80 & 0.459 \\
Periods & 2.04 & 2,80 & 0.136 \\
Treatments & $\mathbf{1 8 . 1 4}$ & $\mathbf{2 , 8 0}$ & $<\mathbf{0 . 0 0 0 1}$ \\
Interaction & 1.97 & 4,80 & 0.106 \\
Meiofauna & & & \\
Habitats & 0.39 & 1,80 & 0.531 \\
Periods & $\mathbf{4 3 . 1 5}$ & $\mathbf{2 , 8 0}$ & $<\mathbf{0 . 0 0 0 1}$ \\
Treatments & 1.61 & 2,80 & 0.207 \\
Interaction & 1.30 & 4,80 & 0.278 \\
\hline
\end{tabular}

Notes: Bold type indicates significant effects $(P<0.05)$. Independent variables are as in Table 1. 


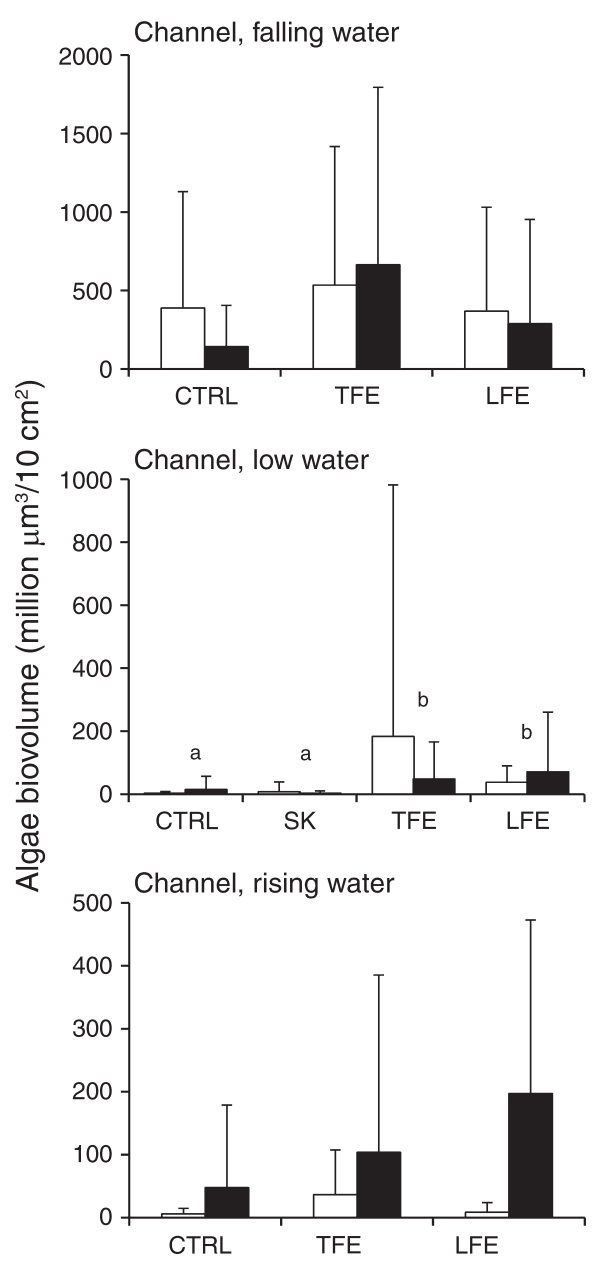

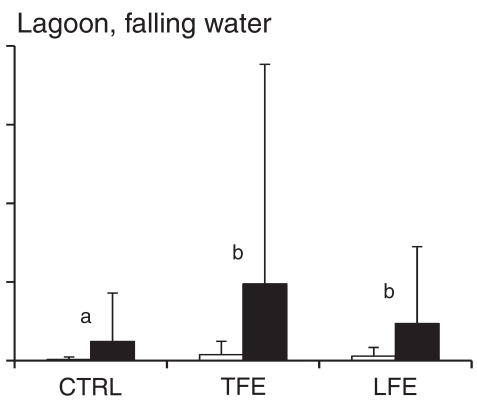

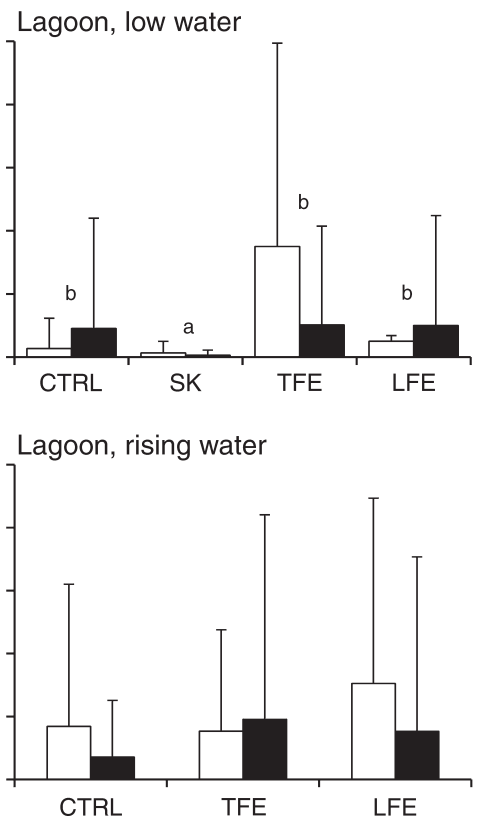

FIG. 4. Biovolume (mean + SE) of the dominant benthic algae taxa (white bars represent Diatomophyceae, black bars represent Zygnematophyceae) from the surface of tiles from 6-d experiments conducted in the river channel and lagoons during three hydrological seasons. Treatments and abbreviations are as in Fig. 2. Different lower-case letters designate significantly different $(P$ $<0.05)$ mean differences between treatments for the combined abundance of Diatomophyceae and Zygnematophyceae.

during the low-water period (Appendix F). Abundances of the three dominant meiofauna taxa (rotifers, crustaceans, and insects) were significantly influenced by hydrologic period, but did not differ significantly between habitat types and experimental treatments (Fig. 5, Table 2, Appendix H). Total meiofauna density in lagoons was nearly three times higher during the lowwater period relative to the rising-water and fallingwater periods; in the river channel, meiofauna density was more than four times higher during the low-water period compared to the rising-water period, and density during the falling-water period was about three times higher (Appendix I). Some individual meiofauna taxa were more common in the river channel and others in lagoons. For example, during the low-water period, copepod densities were higher in the river channel (average $\sim 3.5 \times 10^{5}$ organisms $/ \mathrm{m}^{2}$ ) than in lagoons (average $\sim 2.5 \times 10^{4}$ organisms $/ \mathrm{m}^{2}$; Appendix G). Oligochaete worms showed the same trend (channel $\sim 3 \times 10^{5}$ organisms $/ \mathrm{m}^{2}$, lagoons $\sim 30$ organisms $/ \mathrm{m}^{2}$ ). In contrast, densities of nematodes, rotifers, and testate protozoa were at least twice as abundant in lagoons compared to the channel.

\section{Experimental test of meiofauna effects}

Experimental removal and exclusion of meiofauna from sand resulted in a significant effect for SAFDM within both habitat types (Table 3). When data were combined across habitat types, mean accumulation for the decanted treatment was more than four times greater than the mean for the control; the sterilized treatment had an intermediate mean value that was not significantly different from the other two treatments (Fig. 6). CHLA was significantly influenced by habitat type but not by meiofauna removal treatments (Table 3), even though the mean concentration of the sterilized treatment was more than three times greater than those of the control and decanted treatments (Fig. 6). 


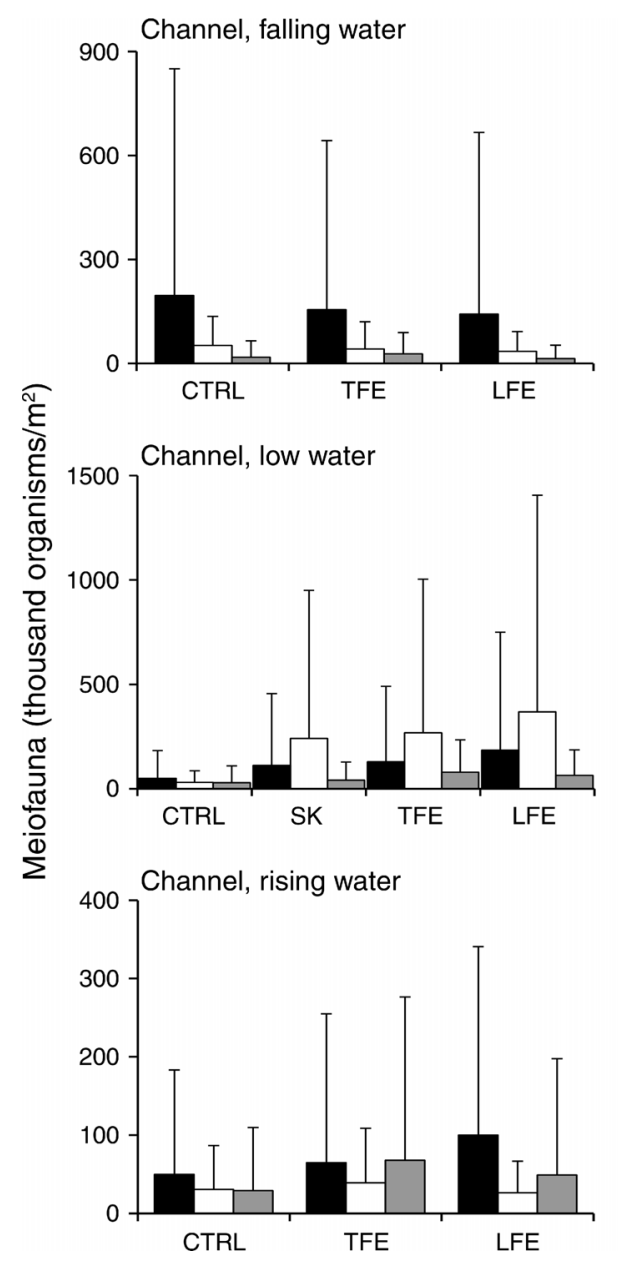

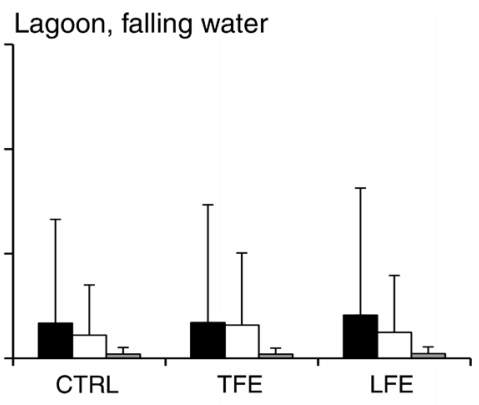
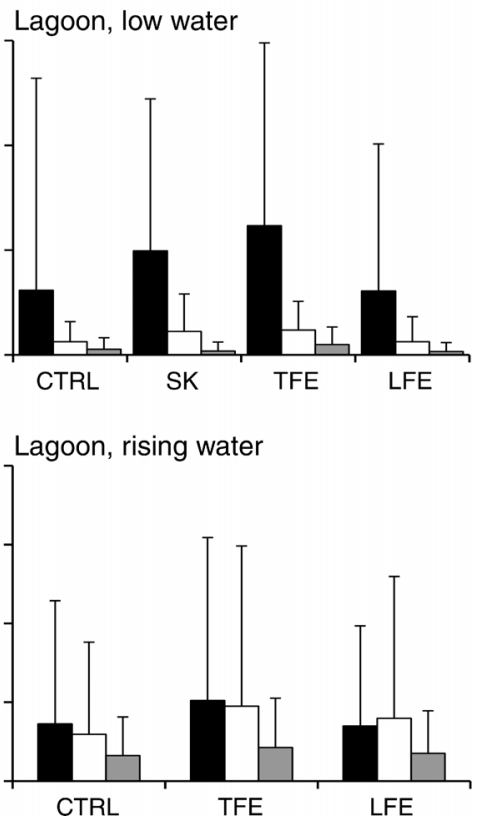

FIG. 5. Density (mean $+\mathrm{SE}$ ) of the dominant meiofauna taxa (black bars represent Rotifera, white bars represent Crustacea, and gray bars represent Insecta) from the top $1 \mathrm{~cm}$ of sand from 6-d experiments conducted in the river channel and lagoons during three hydrological seasons. Treatments and abbreviations are as in Fig. 2. No mean differences were obtained between treatments for any of the three taxa during any of the seasons and habitats; season significantly $(P<0.05)$ affected mean abundance of all three taxa.

\section{Discussion}

Strong seasonal hydrology of the Cinaruco River causes gradual changes in the amount of aquatic habitat and local densities of consumers that, in turn, mediate the relative strength of top-down effects on aquatic basal resources. The gradual drawdown of the annual flood pulse is associated with not only greater concentrations of dissolved inorganic nutrients and densities of resident fishes and aquatic invertebrates (Cotner et al. 2006, Winemiller et al. 2006), but also an influx of migratory benthic-feeding fish. Our findings supported a model of shifting strength of top-down control mediated by changes in hydrograph phase and migrating fish. Experiments manipulating fish and meiofauna indicated that both of these groups significantly affected accumulation of particulate organic matter during the low-water period; fish also affected diatom abundance and chlorophyll on hard substrates. As expected, habitat type and hydrologic period significantly influenced many of the response variables in our experiments.

An important, but difficult, question to address is whether habitat type, hydrologic phase, small fish, large

TABLE 3. Results of ANOVA for experiments testing effects of meiofauna-removal treatments on the accrual of particulate organic material and chlorophyll $a$ within sand in two habitat types (river channel, lagoons) of the Cinaruco River during April 2010 (low-water period).

\begin{tabular}{lccc}
\hline \hline Dependent and independent variable & $F$ & df & $P$ \\
\hline SAFDM & & & \\
$\quad$ Habitats & 1.05 & 1,42 & 0.311 \\
$\quad$ Treatments & $\mathbf{5 . 7 0}$ & $\mathbf{2 , 4 2}$ & $\mathbf{0 . 0 0 6 5}$ \\
$\quad$ Interaction & 0.19 & 2,42 & 0.821 \\
CHLA & & & \\
$\quad$ Habitats & $\mathbf{9 . 9 5}$ & $\mathbf{1 , 4 2}$ & $\mathbf{0 . 0 0 3}$ \\
$\quad$ Treatments & 2.37 & 2,42 & 0.106 \\
$\quad$ Interaction & 2.02 & 2,42 & 0.144
\end{tabular}

Note: Bold type indicates significant effects $(P<0.05)$. 
fish, or meiofauna have the largest influence on fine particulate organic matter on sediments in this river system. Our experimental design provides an opportunity to compare the relative influences of each factor. To estimate a standardized effect size of habitat type (in the absence of effects of fish or hydrologic period), we calculated the ratio of the mean $\log _{10}(\mathrm{SAFDM})$ on tiles for TFE plots in lagoons relative to the mean for TFE plots in the river channel during each period, and then computed the average. This habitat effect size was 0.96 . The effect size of hydrologic phase was estimated as the ratio of mean $\log _{10}$ (SAFDM) values for falling- vs. rising-water and low- vs. rising-water periods, which yielded an estimate of 1.15 , only slightly greater than the effect size of habitat. The effect size of large fish was estimated as the ratio of mean $\log _{10}(\mathrm{SAFDM})$ for LFE vs. CTRL treatments; averaged across hydrologic periods and habitats this value was 1.72. Finally, the effect size of small fishes was estimated as the ratio of mean $\log _{10}$ (SAFDM) for TFE vs. LFE treatments, and the average across hydrologic periods and habitats was 1.05. Thus, large benthic-feeding fish appear to have a much greater influence on accumulations of particulate organic matter on solid substrates in littoral habitats than small fishes, hydrologic phase, and habitat type. Estimated in the same manner, the effect size of meiofauna on accumulation of SAFDM on sand during the low-water period was 1.64, an effect size similar to that of large benthic-feeding fish.

A striking result was the strong fish effect on accumulation of fine particulate organic matter on tiles in contrast to almost no fish effect on sand. This discrepancy suggests that either fish only feed on hard substrates or that other factors eliminated organic matter from sand to negate detection of a fish effect. The first hypothesis is not likely because Semaprochilo$d u s$ were commonly observed feeding on sand within littoral areas. Physical disturbance of sand by fish or flowing water was also unlikely to influence deposition of material on sand, especially given that lagoons had essentially no water flow and nonetheless showed no treatment effects on sand. A more likely explanation is that meiofauna had large effects on organic matter accumulation on sand while having a negligible effect on material accumulating on tile substrate. Meiofaunal organisms apparently were unable to colonize the surface of tiles, as microscopic examination of sediments from tiles revealed almost no meiofauna. Fish, therefore, had nearly exclusive access to resources that accumulate on these solid surfaces. Fish effects on sand were likely more difficult to detect due to consumption of particulate organic material by the meiofauna, and this interpretation was corroborated by results from the meiofauna-exclusion experiment. Meiofauna apparently compete for this key basal resource during the low-water phase of the hydrologic cycle.

The dominant substrate in both channel and lagoon habitats of the river is sand (an estimated $>75 \%$ of the
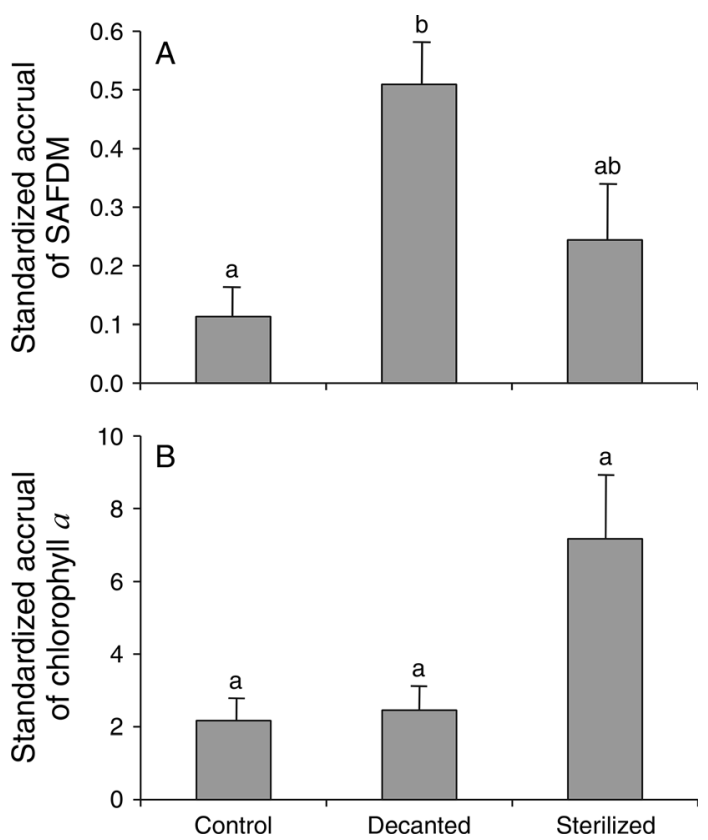

FIG. 6. Standardized accrual ([per-unit-area quantity on day 6] - [quantity on day 0]; mean + SE) of (A) sediment ashfree dry mass (SAFDM) and (B) chlorophyll $a$ in sand samples from meiofauna-removal experiments conducted in 16 river channel and lagoon sites. The difference between the control and treatments (stirred/decanted, sterilized) estimates the effect of meiofauna consumption of organic matter and chlorophyll $a$ over 6 days. Different lower-case letters designate significantly different $(P<0.05)$ mean differences between treatments.

wetted riverscape during the low-water period), but there also are patches of wood, leaf litter, and sedimentary rocks that provide habitat and food resources for certain species of aquatic insects, shrimp, and fishes (Arrington and Winemiller 2006). Morphological (e.g., subterminal or inferior mouth orientation) and dietary evidence suggest that most detritivorous, omnivorous, and invertivorous fishes in this system feed on substrates (Willis et al. 2005). For example, there are several species of loricariid catfishes that scrape periphyton and biofilms from solid substrates, such as wood and rocks. Whether or not most of the material at the surface of substrates originated from the water column, as hypothesized, or from in situ production of benthic algae and microbes, we have shown that the rate of accumulation is rapid, especially during the falling- and low-water periods.

During the low-water period, the meiofauna appears to control, at least partially, the basal resources on sand, particularly fine particulate organic matter, while having a weaker and statistically nonsignificant effect on chlorophyll concentrations. Sterilization of sand sediments probably resulted in slower recolonization by diatoms and meiofauna relative to the stirred/decanted treatment. When trials were initiated, the latter treatment likely contained some living microbial biomass 

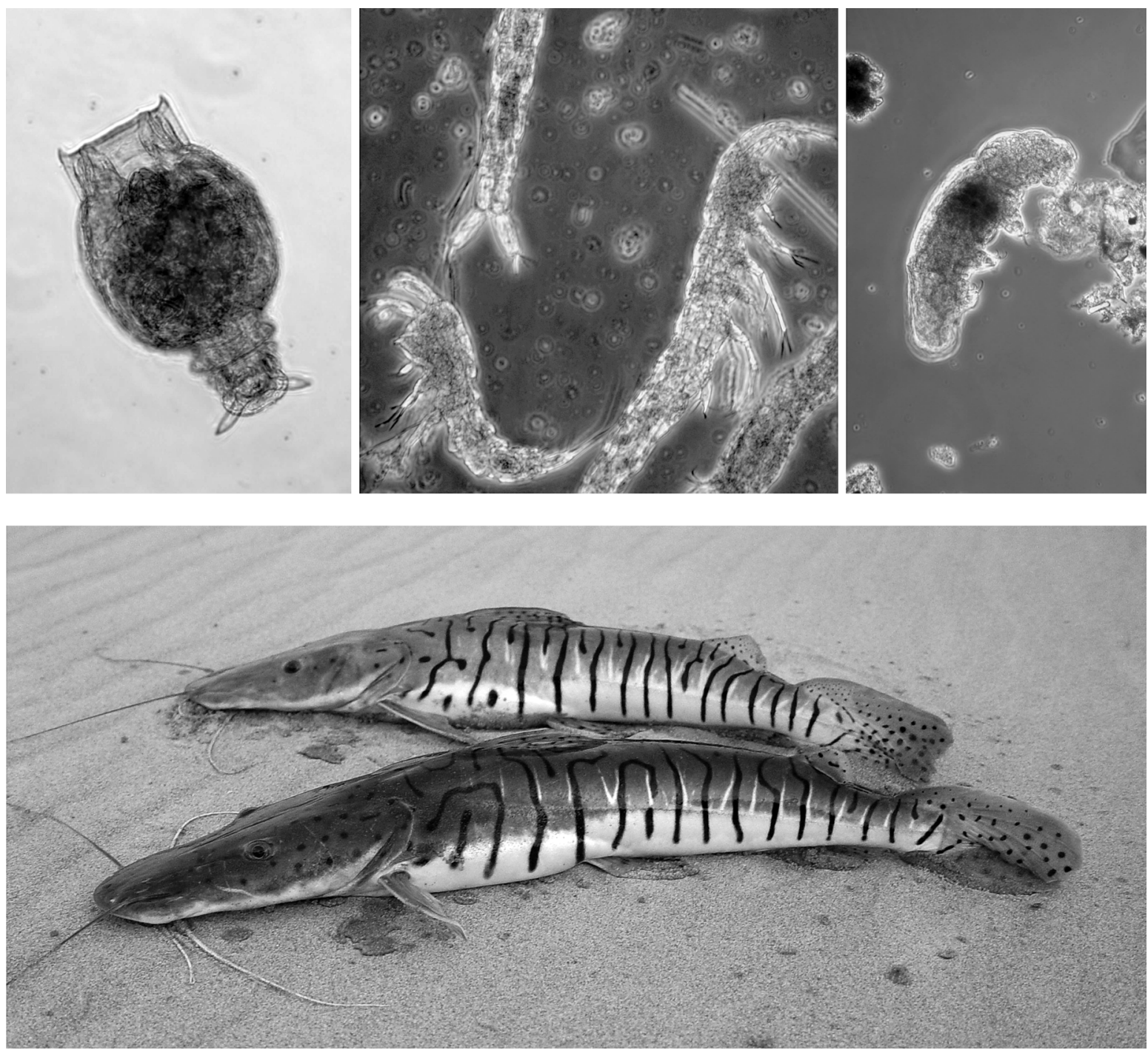

Plate 1. (Top row) Microphotographs of meiofauna from sand of the Cinaruco River in South America: (left) rotifer, (middle) copepods, (right) tardigrade. (Bottom) Two Psuedoplatystoma fasciatum, a predatory catfish that forages at night along the sandy banks of the Cinaruco River, provide a good example of the diverse fish fauna supported by food chains originating from basal resources that accumulate on the sandy substrate. Photo credits: top row, J. V. Montoya; catfish, K. O. Winemiller.

that seeded in situ growth and more rapid accumulation of live organic material. Additional experiments conducted during different periods are needed to quantify consumption of benthic particulate organic matter and algae by meiofauna.

Fish significantly affected chlorophyll concentrations on hard substrates, but in few experiments affected algal assemblage structure. We did, however, document considerable spatiotemporal variation of both algal and meiofauna assemblages in relation to habitat (statistically significant for many taxa) and phases of the flood pulse (significant for nearly all taxa), suggesting that community structure is influenced more by habitat and season than fish. Swan and Palmer (2000) proposed that abiotic factors, such as stream flow and substrate, and dispersal should influence lotic meiofauna assemblages over relatively broad spatial scales, but predation by fishes and macroinvertebrates should affect patterns at the patch scale, with substrate composition mediating predator-prey interactions. In a review of studies investigating effects of benthic macroinvertebrates on meiofauna, Olafsson (2003) found that $84 \%$ of them revealed such evidence, with mechanisms including habitat modification, predation, and competition. Our experiments revealed little evidence that fish affected meiofauna assemblage structure during any hydrological period. One potential explanation is that duration of the experiments was too short to yield a significant response.

Even though we did not detect an effect of fish on meiofauna abundance or assemblage structure, it 
appears, nonetheless, that large benthic-feeding fish, especially the migratory Semaprochilodus, may compete with diverse meiofaunal grazers for fine particulate organic matter on sediments during the low-water phase of the annual hydrologic cycle. Both fish and meiofauna had strong effect sizes on particulate organic matter during the low-water period; fish feeding on tile surfaces apparently were released from competition with meiofauna, and meiofauna apparently confounded detection of top-down effects of fish feeding on sand. Competition between fish and aquatic invertebrates has been demonstrated in other Neotropical rivers. Experimental exclusion of Prochilodus mariae, a migratory prochilodontid that reduces particulate organic matter in sediments of Andean piedmont rivers (Flecker 1996), resulted in a rapid increase in insect biomass and secondary production (Hall et al. 2011). Winter flood pulses in a California river strongly affect aquatic insect assemblages under summer low-flow conditions, which in turn influence the top-down effect of fish on insects and algae (Power et al. 2008). Experiments of longer duration that manipulate the meiofauna in sand and benthic-feeding fish to measure growth responses (e.g., fish body mass, meiofauna collective abundance) could directly test for competition between these distantly related taxa.

In fluvial ecosystems, hydrology is the key environmental driver of ecological dynamics (Winemiller 1990, Wootton et al. 1996, Power et al. 2008, Garcia et al. 2012). In their analysis of 12 years of comparative and experimental research on California's Eel River, Power et al. (2008) identified causal linkages between hydrology, population dynamics as a function of life-history traits, and food-web dynamics. Nonetheless, they were unable to predict fish impacts on algae during a given flood year, which they attributed to the fact that, despite relatively low species diversity and fairly predictable seasonal hydrology, there is considerable interannual variation, with drought years and flood years strongly affecting establishment of dominant aquatic insect populations. Conversely, the Cinaruco River has some attributes that facilitate predictions about population dynamics and food-web interactions (Layman et al. 2005, Winemiller 2007). Most importantly, the river has a highly predictable annual flood pulse that affects dissolved nutrient concentrations, aquatic primary production, and densities of aquatic consumers. This ecosystem is oligotrophic and strongly nitrogen limited, with rapid nutrient cycling (Cotner et al. 2006). Based on stable isotope analysis of resource and consumer tissues, autochthonous primary production supports most of the consumer biomass (Jepsen and Winemiller 2007, Roach et al. 2009). Secondary production is supported to a lesser extent by terrestrial detritus and other allochthonous resources within the vast area of flooded riparian forests and floodplain savannas. Thus, both autochthonous and allochthonous production sources are delivered to consumers in the food web in a predictable and gradual pulsing pattern. This cyclical pulsing causes predictable shifts in the strength of topdown controls of basal resources.

Fine particulate organic matter on substrates appears to be the major basal resource supporting the Cinaruco food web (Layman et al. 2005, Winemiller et al. 2006). Migration of consumers can influence this resource, and thus ecological dynamics, in the receiving system (Polis et al. 1997, Winemiller and Jepsen 1998, 2004, Flecker et al. 2010). In South America, prochilodontid fishes may migrate more than $100 \mathrm{~km}$ between dry-season refugia and flood-season spawning areas (Barbarino Duque et al. 1998). This migratory behavior might be influenced by the relative availability or quality of benthic organic matter pools in different riverscapes, which also may be in different phases of the flood cycle. Migratory fish appear to compete with meiofauna for these resources; however, the meiofauna also provides a productive food resource for diverse and abundant fishes in this system. The Cinaruco fish assemblage ( $\geq 280$ species) is dominated by small species that feed on benthic invertebrates (Arrington and Winemiller 2006, Montaña et al. 2011), and these fishes are themselves consumed by piscivorous fishes (Winemiller 2007; see Plate 1) and birds. Meiofauna populations, therefore, are dynamically important nodes within the network of matter and energy flow.

Network models that simulate food-web dynamics are important tools for management of multispecies fisheries (Christensen and Walters 2011) and other complex systems. Most network models are based on a massbalance approach and incorporate estimates for consumption rates, ratios of standing biomass to production, and other aggregate variables. Fundamental environmental drivers, such as river hydrology (Wootton et al. 1996), oceanographic currents (Menge et al. 2009), and pulsed delivery of nutrients or other resources (Yang et al. 2010) have been shown to modulate food-web dynamics, yet have rarely been integrated into simulation models (Bakun 2010). Understanding of relationships between river hydrology, disturbance regime, productivity, life-history strategies and recruitment, migration, and food-web interactions is improving (Power 1990, Taylor et al. 2006, Power et al. 2008, Cross et al. 2013, Hoagstrom and Turner 2014), such that mechanistic, trait-based community models that incorporate reproduction, feeding, growth, and predation may be able to forecast realistic outcomes (e.g., Persson et al. 2007, Giacomini et al. 2013). Ecosystems with predictable, cyclical pulsing of key environmental drivers provide excellent opportunities to develop models that reliably predict food-web dynamics over interannual time scales.

\section{ACKNOWLEDGMENTS}

This research was funded by NSF grants DEB 0107456, DEB 0089834, and IVIC project no. 937. We thank members of the Cinaruco Fishing Club, especially Edgar Peláez, Carol and Jim Marzuola, and José and Domingo Garcia for invaluable 
logistical support at the Cinaruco River. Aniello Barbarino (Instituto Nacional de Investigaciones Agropecuarias) and Donald Taphorn (Universidade Experimental de los Llanos Occidentales) provided crucial institutional support and assistance throughout the field study. We also thank Wilson García, Pablo Medina, and Alexis Medina for assistance with field research, and Ernesto Aguirre, Meimalin Moreno, Jennifer Snider, and George Gable for assistance with processing benthic samples in the laboratory.

\section{Literature Cited}

Abramoff, M. D., P. J. Magalhaes, and S. J. Ram. 2004. Image processing with ImageJ. Biophotonics International 11:3642.

American Public Health Association (APHA). 1998. Standard methods for the examination of water and wastewater. 20th edition. American Public Health Association, American Water Works Association, and Water Environment Federation, Washington, D.C., USA.

Arrington, D. A., and K. O. Winemiller. 2006. Habitat affinity, the seasonal flood pulse, and community assembly in the littoral zone of a Neotropical floodplain river. Journal of the North American Benthological Society 25:126-141.

Bakun, A. 2010. Linking climate to population variability in marine ecosystems characterized by non-simple dynamics: conceptual templates and schematic constructs. Journal of Marine Systems 79:361-373.

Barbarino Duque, A., D. C. Taphorn, and K. O. Winemiller. 1998. Ecology of the coporo, Prochilodus mariae (Characiformes, Prochilodontidae), and status of annual migrations in western Venezuela. Environmental Biology of Fishes 53:33-46.

Basaguren, A., A. Elosegul, and J. Pozo. 1996. Changes in the trophic structure of benthic macroinvertebrate communities associated with food availability and stream flow variations. Internationale Revue der Gesamten Hydrobiologie und Hydrographie 81:79-91.

Bourrelly, P. 1966. Les algues d'eau douce: initiation à la systematique. I. Les algues vertes. Boubée et Cie, Paris, France.

Bourrelly, P. 1970. Les algues d'eau douce: initiation à la systématique. III. Les algues bleues et rouges, Les Eugléniens, Peridiniens et Cryptomonadines. Boubée et Cie, Paris, France.

Christensen, V., and C. J. Walters. 2011. Progress in the use of ecosystem modeling for fisheries management. Pages 189-205 in V. Christensen and J. L. Maclean, editors. Ecosystem approaches to fisheries: a global perspective. Cambridge University Press, Cambridge, UK.

Clarke, K. R. 1993. Non-parametric multivariate analyses of changes in community structure. Australian Journal of Ecology 18:117-143.

Clarke, K. R., and R. M. Warwick. 2001. Change in marine communities: an approach to statistical analysis and interpretation. Second edition. PRIMER-E, Plymouth, UK.

Cotner, J. B., J. V. Montoya, D. L. Roelke, and K. O. Winemiller. 2006. Seasonal variability in benthic and water column productivity in a Venezuelan llanos river. Journal of the North American Benthological Society 25:171-184.

Cross, W. F., C. V. Baxter, E. J. Rosi-Marshall, R. O. Hall, Jr., T. A. Kennedy, K. C. Donner, H. A. Wellard Kelly, S. E. Z. Seegert, K. E. Behn, and M. D. Yard. 2013. Food-web dynamics in a large river discontinuum. Ecological Monographs 83:311-337.

Flecker, A. S. 1996. Ecosystem engineering by a dominant detritivore in a diverse tropical stream. Ecology 77:18451854.

Flecker, A. S., P. B. McIntyre, J. W. Moore, J. T. Anderson, B. W. Taylor, and R. O. Hall. 2010. Migratory fishes as material and process subsidies in riverine ecosystems. American Fisheries Society Symposium 73:559-592.

Garcia, A. M., J. P. Vieira, K. O. Winemiller, L. E. Moraes, and E. T. Paes. 2012. Factoring scales of spatial and temporal variation in fish abundance and environmental correlates in a subtropical estuary. Marine Ecology Progress Series 461:121135.

Giacomini, H. C., D. L. DeAngelis, J. C. Trexler, and M. Petrere, Jr. 2013. Trait contributions to fish community assembly emerge from trophic interactions in an individualbased model. Ecological Modeling 251:32-43.

Hall, R. O., Jr., B. W. Taylor, and A. S. Flecker. 2011. Detritivorous fish indirectly reduce insect secondary production in a tropical river. Ecosphere 2:1-13.

Hasle, G. R., and G. A. Fryxell. 1970. Diatoms: cleaning and mounting for light and electron microscopy. Transactions of the American Microscopical Society 89:469-474.

Hillebrand, H., C. D. Duerselen, D. B. Kirschtel, U. Pollinger, and T. Zohary. 1999. Biovolume calculation for pelagic and benthic microalgae. Journal of Phycology 35:403-424.

Hoagstrom, C. W., and T. F. Turner. 2014. Recruitment ecology of pelagic-broadcast spawning minnows: paradigms from the ocean advance science and conservation of an imperiled freshwater fauna. Fish and Fisheries, in press.

Jepsen, D. B., and K. O. Winemiller. 2007. Basin geochemistry and isotopic ratios of fishes and basal production sources in four Neotropical rivers. Ecology of Freshwater Fish 16:267281.

Krammer, K., and H. Lange-Bertalot. 1988. "Susswasserflora von Mitteleuropa". Bacillariophyceae Teil ii: Bacillariaceae, Epithemiaceae, Surirellaceae. Gustav Fischer Verlag, Stuttgart, Germany.

Krammer, K., and H. Lange-Bertalot. 1991. "Susswasserflora von Mitteleuropa". Bacillariophyceae Teil iii: Centrales, Fragilariaceae, Eunotiaceae. Gustav Fischer Verlag, Stuttgart, Germany.

Layman, C. A., K. O. Winemiller, and D. A. Arrington. 2005. Describing a species-rich river food web using stable isotopes, stomach contents, and functional experiments. Pages 395406 in P. C. de Ruiter, V. Wolters, and J. C. Moore, editors. Dynamic food webs: multispecies assemblages, ecosystem development and environmental change. Elsevier, Amsterdam, Netherlands.

Marcarelli, A. M., C. V. Baxter, M. M. Mineau, and R. O. Hall, Jr. 2011. Quantity and quality: unifying food web and ecosystem perspectives on the role of resource subsidies in freshwaters. Ecology 92:1215-1225.

McIntyre, P. B., A. S. Flecker, M. J. Vanni, J. M. Hood, B. W. Taylor, and S. A. Thomas. 2008. Fish distributions and nutrient cycling in streams: can fish create biochemical hotspots? Ecology 89:2335-2346.

Medina, E., and J. F. Silva. 1990. Savannas of northern South America: a steady state regulated by water-fire interactions on a background of low nutrients availability. Journal of Biogeography 17:403-413.

Menge, B. A., F. Chan, K. J. Nielsen, E. DiLorenzo, and J. Lubchenco. 2009. Climatic variation alters supply-side ecology: impact of climate patterns on phytoplankton and mussel recruitment. Ecological Monographs 79:379-395.

Metzelin, D., and H. Lange-Bertalot. 1998. Tropical diatoms of South America I: about 700 predominantly rarely known or new taxa representative of the neotropical flora. Pages 1-695 in $\mathrm{H}$. Lange-Bertalot, editor. Iconographia diatomologica. Annotated diatom micrographs. Volume 5: diversity-taxonomy-geobotany. Koeltz Scientific Books, Königstein, Germany.

Montaña, C. G., C. A. Layman, and K. O. Winemiller. 2011. Gape size influences seasonal patterns of piscivore diets in three Neotropical rivers. Neotropical Ichthyology 9:647-655. 
Montoya, J. V., D. L. Roelke, K. O. Winemiller, J. B. Cotner, and J. Snider. 2006. Hydrological seasonality and benthic algal biomass in a Neotropical floodplain river. Journal of the North American Benthological Society 25:157-170.

Nauwerck, A. 1963. Die beziehungen zwischen zooplankton und phytoplankton im See Erken. Symbolae Botanicae Upsalienses 17:1-163.

Olafsson, E. 2003. Do macrofauna structure meiofauna assemblages in marine soft-bottoms? A review of experimental studies. Vie Milieu 53:249-265.

Palmer, M. A., D. L. Strayer, and S. D. Rundle. 2007. Meiofauna. Pages 415-433 in F. R. Hauer and G. A. Lamberti, editors. Methods in stream ecology. Academic Press (Elsevier), Burlington, Massachusetts, USA.

Persson, L., P. A. Amundsen, A. M. De Roos, A. Klemetsen, R. Knudsen, and R. Primicerio. 2007. Culling prey promotes predator recovery - alternative states in a whole-lake experiment. Science 316:1743-1746.

Polis, G. A., W. B. Anderson, and R. D. Holt. 1997. Toward an integration of landscape and food web ecology: the dynamics of spatially subsidized food webs. Annual Review of Ecology and Systematics 28:289-316.

Power, M. E. 1990. Effects of fish in river food webs. Science 250:811-814.

Power, M. E. 1992. Habitat heterogeneity and the functional significance of fish in river food webs. Ecology 73:1675-1688.

Power, M. E., M. S. Parker, and W. E. Dietrich. 2008. Seasonal reassembly of a river food web: floods, droughts, and impacts of fish. Ecological Monographs 78:263-282.

Pringle, C. M., and T. Hamazaki. 1997. Effects of fishes on algal response to storms in a tropical stream. Ecology 78:2432-2442.

Roach, K. A., K. O. Winemiller, C. A. Layman, and S. C. Zeug. 2009. Consistent trophic patterns among fishes in lagoon and channel habitats of a tropical floodplain river: evidence from stable isotopes. Acta Oecologia 35:513522.

Roelke, D. L., J. B. Cotner, J. V. Montoya, C. E. Del Castillo, S. E. Davis, J. A. Snider, G. M. Gable, and K. O. Winemiller. 2006. The role of allochthonous organic matter and inorganic nutrients in a tropical blackwater river and associated lagoon: comparisons during low- and falling-water periods. Journal of the North American Benthological Society 25:185-197.

Sarmiento, G., and M. Pinillos. 2001. Patterns and processes in a seasonally flooded tropical plain: the Apure Llanos, Venezuela. Journal of Biogeography 28:985-996.
Sun, J., and D. Liu. 2003. Geometric models for calculating cell biovolume and surface area for phytoplankton. Journal of Plankton Research 25:1331-1346.

Swan, C. M., and M. A. Palmer. 2000. What drives small-scale patterns in lotic meiofauna communities? Freshwater Biology 44:109-121.

Taylor, B. W., A. S. Flecker, and R. O. Hall, Jr. 2006. Loss of a harvested fish species disrupts carbon flow in a diverse tropical river. Science 313:833-836.

Utermöhl, H. 1958. Zur vervollkommung der quantitative phytoplanktonmethodik. Verhandlungen der Internationalen Vereinigung für Theoretische und Angewandte Limnologie 9:1-38.

Willis, S. C., K. O. Winemiller, and H. López-Fernández. 2005. Habitat structural complexity and morphological diversity of fish assemblages in a Neotropical floodplain river. Oecologia 142:284-295.

Winemiller, K. O. 1990. Spatial and temporal variation in tropical fish trophic networks. Ecological Monographs 60:331-367.

Winemiller, K. O. 2007. Interplay between scale, resolution, life history and food web properties. Pages 101-126 in K. McCann, D. Noakes, and N. Rooney, editors. From energetics to ecosystems: the dynamics and structure of ecological systems. Springer, Dordrecht, Netherlands.

Winemiller, K. O., and D. B. Jepsen. 1998. Effects of seasonality and fish movement on tropical river food webs. Journal of Fish Biology 53(Supplement A):267-296.

Winemiller, K. O., and D. B. Jepsen. 2004. Migratory Neotropical fish subsidize food webs of oligotrophic blackwater rivers. Pages 115-132 in G. A. Polis, M. E. Power, and G. R. Huxel, editors. Food webs at the landscape level. University of Chicago Press, Chicago, Illinois, USA.

Winemiller, K. O., J. V. Montoya, C. A. Layman, D. L. Roelke, and J. B. Cotner. 2006. Experimental demonstrations of seasonal fish effects on benthic ecology of a Neotropical floodplain river. Journal of the North American Benthological Society 25:250-262.

Woodward, G., and A. G. Hildrew. 2002. Food web structure in riverine landscapes. Freshwater Biology 47:777-798.

Wootton, J. T., M. S. Parker, and M. E. Power. 1996. Effects of disturbance on river food webs. Science 273:1558-1561.

Yang, L. H., J. L. Bastow, K. O. Spence, and A. N. Wright. 2008. What can we learn from resource pulses? Ecology 89:621-643.

Yang, L. H., K. F. Edwards, J. E. Byrnes, J. L. Bastow, A. N. Wright, and K. O. Spence. 2010. A meta-analysis of resource pulse-consumer interactions. Ecological Monographs 80:125-151.

\section{Supplemental Material}

Ecological Archives

Appendices A-I are available online: http://dx.doi.org/10-1890/13-1822.1.sm

Data Availability

Data associated with this paper have been deposited in the Dryad repository: http:dx.doi.org/10.5061/dryad.f4211 